\title{
Akut Böbrek Yetmezliği Tanısıyla Kliniğimize Yatan Olguların Analizi
}

\author{
Analysis of Patients Hospitalized in Our Clinic with the Diagnosis of Acute Renal Failure
}

\author{
Ahmet AHSEN ${ }^{1}$, Memnune Sena ULU², Şeref YÜKSEL ${ }^{3}$, \\ Kasım DEMIR ${ }^{4}$, Mükremin UYSAL ${ }^{5}$, Gürsel ACARTÜRK ${ }^{6}$ \\ ${ }^{1}$ Yrd.Doç.Dr. Afyon Kocatepe Üniversitesi Tıp Fakültesi, i̧̧̇ Hastalıkları AD, Afyonkarahisar \\ ${ }^{2}$ Yrd.Doç.Dr.Afyon Kocatepe Üniversitesi Tıp Fakültesi, İç Hastalıkları AD, Nefroloji Bilim Dalı, Afyonkarahisar \\ ${ }^{3}$ Doç.Dr.Afyon Kocatepe Üniversitesi Tıp Fakültesi, İç Hastalıkları AD, Nefroloji Bilim Dalı, Afyonkarahisar \\ ${ }^{4}$ Uzm.Dr.Afyon Kocatepe Üniversitesi Tıp Fakültesi, İ̧̧ Hastalıkları AD, Gastroenteroloji Bilim Dalı, Afyonkarahisar \\ ${ }^{5}$ Yrd.Doç.Dr.Afyon Kocatepe Üniversitesi Tıp Fakültesi, İç Hastalıkları AD, Medikal Onkoloji Bilim Dalı, Afyonkarahisar, \\ ${ }^{6}$ Doç.Dr. Afyon Kocatepe Üniversitesi Tıp Fakültesi, iç̧ Hastalıkları AD, Gastroenteroloji Bilim Dalı, Afyonkarahisar
}

Geliş Tarihi / Received: 13.12.2013

Kabul Tarihi / Accepted: 27.01.2014

\section{ÖZET}

Amaç: Akut böbrek yetmezliği, böbrek fonksiyonlarında hızlı bir azalmayla karakterize ve yüksek mortalite oranına sahip önemli bir klinik sendromdur. Akut böbrek yetmezliğinde mortalite, son yıllardaki yoğun bakım ve renal replasman tedavilerindeki gelişmeye rağmen yüksek kalmaya devam etmektedir. Bu çalışmada kliniğimizde ABY tanısıyla yatan hastaları değerlendirdik.

Gereç ve Yöntem: Ocak 2011 ve Aralık 2012 arasında hastanemize Akut böbrek yetmezliği tanısıyla başvuran 145 hastayı retrospektif olarak inceledik. Hastaların kayıtlarından yaşı, Akut böbrek yetmezliği tipi, başvuru şekli, başvurudaki temel bulguları, etyolojisi, zeminde eşlik eden hastalıklar, uygulanan tedavi ve laboratuvar değerleri kaydedildi.

Bulgular: Olguların etiyolojisi incelendiğinde en sık nedenler prerenal azotemi $(\% 38,6)$ ve nefrotoksik ajan kullanımıydı $(\% 30,3)$. Hastaların \%72,6'sı nonoligürik \%27,4'ü oligürik idi. Olguların \%65,5'ine medikal tedavi uygulanırken $\% 34,5$ 'ine medikal tedaviye ek olarak hemodiyaliz tedavisi uygulandı. Hastaların \%86,9'u tedavi sonucu iyileşirken, \%13,1'i kaybedildi. Ölen hastaların \%63,2'si medikal tedaviye ek olarak hemodiyaliz tedavisi alırken $\% 36,8^{\prime} i$ sadece medikal tedavi almışt. Oligürik hastaların \%67,5'i medikal tedavi ve hemodiyaliz, \%32,5'i sadece medikal tedavi alırken nonoligürik hastaların \%21,9'u medikal tedavi ve hemodiyaliz, \%78,1'i sadece medikal tedavi aldı.

Sonuç: Akut böbrek yetmezliği etiyolojisinde 40 yıl öncesine göre medikal nedenler ön plana çıkmaktadır. Ayrıca oligoa-

Yazışma Adresi / Correspondence: Yrd. Doç. Dr. Ahmet AHSEN Adres: Afyon Kocatepe Üniversitesi Tıp Fakültesi İç Hastalıkları AD. AFYONKARAHISAR

e-posta: ahmetahsen@gmail.com nürik Akut böbrek yetmezliği hastalarında diyaliz gereksiniminin arttı̆ı ve diyaliz tedavisi gereken hastalarda prognozun daha kötü olduğu gözlenmiştir. Bu yüzden bu hastaların daha yakından izlenmesi gerekmektedir.

Anahtar Kelimeler: Akut böbrek yetmezliği, Oligüri, Hemodiyaliz

\section{ABSTRACT}

Objective: Acute renal failure, which is characterized by a speedy decrease in renal function, is an important clinical syndrome with a high mortality rate. In spite of advanced intensive care and renal replacement therapies in recent years, Acute renal failure mortality continues to remaining high . In this study, we evaluated patients hospitalized with ARF.

Material and Methods: We reviewed 145 patients with a diagnosis of Acute renal failure between January 2011 and December 2012 in our hospital, retrospectively. From the records of the patients, age, Acute renal failure type, application form, application of the basic findings, etiology, concomitant diseases, treatment, and laboratory values were recorded.

Results: The most common causes of Acute renal failure etiology in our hospital were prerenal azotemia (38.6\%) and nephrotoxic agents $(30.3 \%)$. The $72.6 \%$ of patients were nonoliguric, while $27.4 \%$ were oliguric. Medical treatment was applied to $65.5 \%$ of patients and medical management together with hemodialysis therapy was administered to the rest of the patients. The improvement rate of patients was $869 \%$ while $13.1 \%$ of the patients were lost. The $63.2 \%$ of dying patients were treated with hemodialysis treatment in addition to medical treatment, while $36.8 \% \mathrm{had}$ received medical treatment only. The $21.9 \%$ of nonoliguric patients had received hemodialysis and medical treat- 
ment and $78.1 \%$ of them received only medical treatment. Conclusion: According to the etiology of Acute renal failure, medical reasons come to the forefront compared with 40 years ago. It is also observed that the need for dialysis in Acute renal failure patients with oligoanuria increased and the patients who require dialysis have worse prognosis. Therefore, these patients should be monitored more closely.

Key words: Acute renal failure, Oliguria, Hemodialysis

\section{GiRiş}

Akut Böbrek Yetmezliği (ABY) renal fonksiyonda hızlı bir azalmayla karakterize ve yüksek mortalite oranına sahip önemli bir klinik sendromdur (1). Glomerüler filtrasyon hızındaki (GFR) düşüşün aylar hatta yıllar içerisinde geliştiği kronik böbrek yetmezliğinin aksine, akut böbrek yetmezliğindeki GFR düşüşü daha hızlıdır ve günler ile haftalar içerisinde gelişir (2). Etyolojik olarak toplumların ekonomik durumu, çevresel faktörler ve yaş gibi nedenlerle yakından ilişkilidir $(3,4)$. Etyolojik faktörler prerenal, renal ve postrenal nedenler olmak üzere üç grupta incelenir. Prerenal azotemi en sık etyolojik faktör olarak görülürken, bunu renal parankim hasarı yapan nefrotoksik ilaçlar, akut glomerülonefrit, sepsis gibi durumlar ve daha az olarak da postrenal nedenler izler $(5,6)$. Tedavide, etyolojiye ve gelişen komplikasyonlara göre konservatif tedavi veya hemodiyaliz tedavisi uygulanır. ABY'de mortalite oranı, son yıllarda yoğun bakım üniteleri ve renal replasman tedavisindeki gelişmelere rağmen yüksek kalmaya (\%20 -40) devam etmektedir $(7,8)$.

Bu çalışmada, kliniğimizde ABY tanısıyla yatarak tedavi gören hastaların etyolojisi, klinik özellikleri, laboratuvar bulguları, tedavi şekillerini ve mortalite oranını değerlendirdik.

\section{GEREÇ ve YÖNTEM}

Bu çalışmada, Ocak 2011 ve Aralık 2012 tarihleri arasında Afyon Kocatepe Üniversitesi Tıp Fakültesi Hastanesi Acil servis, Nefroloji ve İç Hastalıkları Polikliniklerine başvurusunda $A B Y$ tanısı alan, İç hastalıkları ve Nefroloji kliniklerinde yatarak tedavi gören 145 hasta retrospektif olarak incelenmiştir.

Hastaların tanısı, anamnez, fizik muayene, laboratuvar değerleri ve klinik izlem ile konuldu. Tanıda bazal serum kreatinin değerine göre en az $0,3 \mathrm{mg} / \mathrm{dl}$ veya \%50'lik_artiş saptanan hastalar ya da alt saattir 0,5 ml/ $\mathrm{kg} /$ saat'ten az idrar çıkışı olan hastalar ABY olarak değerlendirildi (9). Hastaların kayıtlarından yaşı, ABY tipi, başvuru şekli, başvurudaki temel bulguları, etyolojisi, zeminde eşlik eden hastalıklar, uygulanan tedavi ve laboratuvar değerleri kaydedildi.İstatistiksel analiz:

İstatistiksel hesaplamalar için, SPSS istatistik programı (SPSS, versiyon 17.0. Inc. Chicago, IL, ABD) kullanıldı. Sürekli değişkenler ortalama \pm SD ve kategorik değişkenler yüzde olarak ifade edildi. Kolmogorov-Smirnov testi değişkenlerin dağılımını değerlendirmek için kullanıldı. Student t-testi normal dağılımlı sürekli değişkenler için ve Mann-Whitney $U$ testi ise normal dağııımı olmayan sürekli değişkenler için kullanıldı. Ki-kare testi, kategorik değişkenler için kullanılmıştır. Normal dağılım durumuna göre değişkenlerin ilişki analizleri Pearson korelasyon analizi veya Spearman korelasyon analizi ile değerlendirildi. $\mathrm{P}<0.05$ değeri anlamlı düzeyde olarak kabul edildi.

\section{BULGULAR}

Çalışmamıza alınan bireylerin yaş ortalaması $68,17 \pm$ 15,59 ve $\% 58,6$ 'sı erkek, \%41,4'ü kadın idi.Tanısal olarak değerlendirildiğinde \%85,5'i ABY, \%14,5'si KBY zemininde gelişen $A B Y$ ve $\% 72,6^{\prime}$ si nonoligürik, $\% 27,4^{\prime} i$ oligürik idi. Hastaların \%41,4'si acil serviste, \%46,9'ü poliklinikte tanı konularak hastanemize yatırılırken \%11,7'si ise diğer servislerden devir alındı. Hastalarımıza ait sosyodemografik, laboratuvar ve tanı özellikleri tablo 1'de gösterildi.

Hastaların kliniğe kabulü sırasındaki temel bulgular arasında, \%47,6 ile üremik semptomlar ilk sırada yer alırken, \%20 hastada hiperkalemi ikinci sıklıkta görülen bulguydu (Tablo 2). Etiyolojik olarak incelendiğinde ise, prerenal azotemi \%38,6 ile ilk sırada, nefrotoksik ilaç kullanımı \%30,3 ise ikinci sırada gözlenmekteydi (Tablo 3). Çalışmaya alınan hastalarda ek hastalık olarak, olguların \%42,1'inde Hipertansiyon(HT), \%26,9'unda Diyabetes Mellitus, \%22,1'inde Koroner Arter Hastalığ mevcuttu (Tablo 4).

Olguların \%65,5'ine ( $n=95)$ sadece medikal tedavi uygulanırken, \%34,5'inde $(n=50)$ medikal tedaviye ek olarak hemodiyaliz tedavisi uygulandı. Hastaların \%86,9'u (n=126) tedavi sonucu iyileşirken, \%13,1'i 
Tablo 1: Hastaları tanı tipleri, sosyodemografik ve laboratuar özellikleri

\begin{tabular}{|c|c|c|}
\hline & & $\mathrm{n}$ \\
\hline Yaş, yıl & & $68.17 \pm 15.59$ \\
\hline Cinciut $n$ (O) & Erkek & $85(58.6)$ \\
\hline 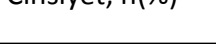 & Kadın & $60(41.4)$ \\
\hline Tand n(o) & ABY & $124(85.5)$ \\
\hline (10m, & $K B Y+A B Y$ & $21(14.5)$ \\
\hline ADV Tini n lOo & Nonoligürik & $105(72.6)$ \\
\hline ) & Oligürik & $40(27.4)$ \\
\hline $\mathrm{Hb}, \mathrm{g} / \mathrm{dl}$ & & $11.25 \pm 1.97(6.7-16.6)$ \\
\hline $\mathrm{Htc}, \%$ & & $34.6 \pm 5.92(20-55)$ \\
\hline Wbc, $10^{3} \mathrm{xmm}^{3}$ & & $12.44 \pm 8.67(1.44-59)$ \\
\hline $\mathrm{ESR}, \mathrm{mm} / \mathrm{h}$ & & $58.24 \pm 40.45(1-164)$ \\
\hline CRP, $\mathrm{mg} / \mathrm{dl}$ & & $10.13 \pm 10.16(0.1-42.4)$ \\
\hline $\mathrm{BUN}, \mathrm{mg} / \mathrm{dl}$ & & $61.44 \pm 30.58(17.5-150)$ \\
\hline Kreatinin, mg/dl & & $3.59 \pm 2.56(1.35-15.3)$ \\
\hline $\mathrm{Na}, \mathrm{mEq} / \mathrm{L}$ & & $136.14 \pm 5.6(119-155)$ \\
\hline $\mathrm{K}, \mathrm{mEq} / \mathrm{L}$ & & $5.22 \pm 1.25(2.8-8.1)$ \\
\hline $\mathrm{Ca}, \mathrm{mg} / \mathrm{dL}$ & & $8.77 \pm 1.07(6.4-14.5)$ \\
\hline $\mathrm{P}, \mathrm{mg} / \mathrm{dL}$ & & $4.97 \pm 2.00(1.3-12.8)$ \\
\hline PTH, pg/mL & & $133.46 \pm 122.22(9-686)$ \\
\hline
\end{tabular}

*Aksi bildirilmedikçe veriler, ortalama \pm SD olarak verilmiştir

**ABY: akut böbrek yetmezliği, KBY:kronik böbrek yetmezliği, ESR: eritrosit sedimentasyon hızı, CRP: C-reaktif protein, BUN:kan üre azotu, PTH:parathormon

Tablo 2: Hastaların başvuru sırasındaki temel bulguları.

\begin{tabular}{|l|l|}
\hline & $\mathrm{n}(\%)$ \\
\hline Üremik semptomlar & $69(47.6)$ \\
\hline Hiperkalemi & $29(20.0)$ \\
\hline Hipervolemi & $17(11.7)$ \\
\hline Asidoz & $16(11.0)$ \\
\hline Asidoz + Hiperkalemi & $10(6.9)$ \\
\hline Hipervolemi + Hiperkalemi & $4(2.8)$ \\
\hline
\end{tabular}

Tablo 3: ABY'ne yol açan nedenler.

\begin{tabular}{|l|l|}
\hline & $\mathrm{n}(\%)$ \\
\hline Prerenal nedenler & $56(38.6)$ \\
\hline Nefrotoksik ilaç kullanımı & $44(30.3)$ \\
\hline Enfeksiyon & $20(13.8)$ \\
\hline Radyokontrast ajan maruziyeti & $7(4.8)$ \\
\hline Akut glomerülonefrit & $9(6.2)$ \\
\hline Postrenal nedenler & $9(6.2)$ \\
\hline
\end{tabular}


Tablo 4: Eşlik eden hastalıklar.

\begin{tabular}{|l|l|}
\hline & $\mathrm{n}(\%)$ \\
\hline Sistemik hipertansiyon & $32(22.1)$ \\
\hline Koroner arter hastalığı & $19(13.1)$ \\
\hline DM+HT & $16(11.0)$ \\
\hline DM+HT+KAH & $13(9.0)$ \\
\hline DM & $10(6.9)$ \\
\hline KOAH & $6(4.1)$ \\
\hline Malignite & $12(8.3)$ \\
\hline Kronik karaciğer hastalığı & $1(0.7)$ \\
\hline Ek hastalık yok & $36(24.8)$ \\
\hline
\end{tabular}

DM: Diabetes mellitus, HT: Hipertansiyon, KAH: Koroner arter hastalığı, KOAH: Kronik obstrüktif akciğer hastalığı

( $n=19)$ kaybedildi. Ölen hastalardan \%63,2'si ( $n=12)$ medikal tedavi ile birlikte hemodiyaliz tedavisi alırken, sadece medikal tedavi alanlar \%36,8 $(n=7)$ oranınday$d_{\imath}(p=0,005)$ (Şekil 1$)$.

Oligürik ve nonoligürik hastalar arasında yaş ortalamaları, etiyolojik faktör ve eşlik eden hastalık yönünden bir fark yoktu $(p>0,05)$. Oligürisi olan hastaların $\% 67,5^{\prime}$ ine $(n=27)$ medikal tedavi ile birlikte hemodiyaliz uygulanırken, \%32,5'sına ( $n=13$ ) sadece medikal tedavi uygulandı. Non-oligürik hastaların ise \%21,9'una $(n=23)$ medikal tedavi ve hemodiyaliz uygulanırken, $\% 78,1$ 'ine (82) sadece medikal tedavi uygulandı $(p<0,001)$ (Şekil 2).

Mortalite ile ilişkili olabilecek faktörler incelendiğinde; ABY ile birlikte DM olan hastaların \%84,6'sı ( $n=33$ ) iyileşirken, \%15,4'ü ( $n=6)$ kaybedildi. DM olmayan has-

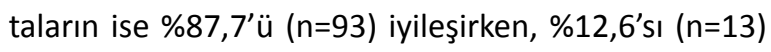
kaybedildi. Diyabeti olan hastalardaki mortalite, diyabet olmayan hastalara göre daha fazla olmasına olmasına rağmen istatiksel olarak anlamlı düzeyde değildi (sırasıyla; $\% 15,4$ ve $\% 12,3) \quad(p=0,621)$. Günlük idrar miktarı ile mortalite ilişkisi değerlendirildiğinde, oligürik hastaların mortalite oranı \%15 iken nonoligürik hastaların mortalite oranı $\% 12,4$ idi. Oligürisi olan ve olmayan hastalar arasında, mortalite açısından istatiksel olarak anlamlılık düzeyine ulaşmayan bir fark vardı $(p=0,676)$. Hastaların yaşı ile mortalite arasındaki ilişki incelendiğinde, ölen hastalar ile sağ kalan hastaların yaş ortalaması arasında anlamlı bir fark bulunmadı (hastaların yaş ortalamaları sırasıyla $70,4 \pm 12,49$ ve $67,8 \pm 16,02)(p=0,503)$.
Kreatinin değerlerinin mortaliteye etkisine bakıldığın$\mathrm{da}$, geliş kreatinin seviyeleri $3 \mathrm{mg} / \mathrm{dl}$ üzerinde olanlardaki mortalite oranında, $3 \mathrm{mg} / \mathrm{dl}$ altında olanlar arasında anlamlı bir fark yoktu (sırasıyla \%17 ve \%12) $(p=0,49)$. Geliş kreatinin değerleri ile mortalite arasındaki korelasyon incelendiğinde, herhangi bir ilişki saptanmadı ( $r:-0,093, p=0,267)$.

\section{TARTIŞMA}

Gelişmiş ülkelerde, $A B Y^{\prime}$ nin etyolojisinde, 40 yı öncesine kadar cerrahi komplikasyonlar, obstetrik nedenler ve travma ön plandayken, son 30 yıldır medikal problemler daha belirgin hale gelmiştir (10-14). Biz çalışmamızda $A B Y$ 'nin en sık nedenini medikal nedenler olarak bulduk. Ayrıca hastaların idrar miktarı ile mortalite arasında fark bulunmazken, diyaliz gereksinimi olan hastalardaki mortalite oranı diyaliz gerekmeyenlere göre fazlaydı.

San ve ark. ABY'li 438 hastada yaptıkları çalışmada, hastaların \%31'inde başlıca etyolojik neden olarak hipovolemi bulmuşlardır (15). Bir başka çalışmada Utaş ve ark. 1983-1997 arasındaki ABY değerlendirmelerinde medikal nedenleri sırasıyla \%59 olarak bulmuşlardır. Medikal nedenlerden \%30,5'i nefrotoksik ilaçlara bağlıyken, \%40,3'ü hipovolemiye (prerenal azotemi) bağlıydı (5). Altıntepe ve ark. 181 hastayı incelemişler ve $\% 22,2$ nefrotoksik ajanlar, \%23,9 prerenal azotemik nedenler bulmuşlardır (16). Öztürk ve ark. ise 192 hastalık çalışmalarında, etyolojide $\% 19,7$ oranında nefrotoksik ajana maruziyet, \%12,4 prerenal azotemi 


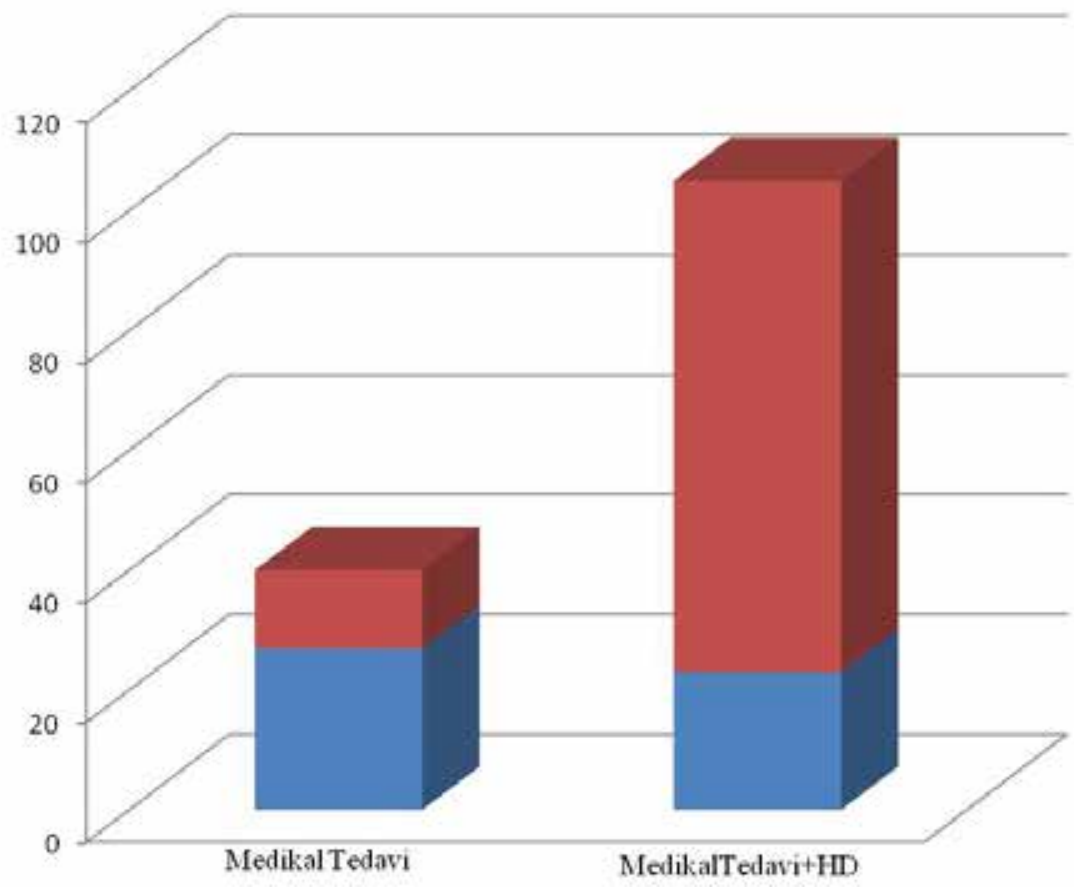

- Tedaviye Cevap Verenler

- ExOlanlar

Şekil 1: Hastalara uygulanan tedavi şekilleri ve sonuçları

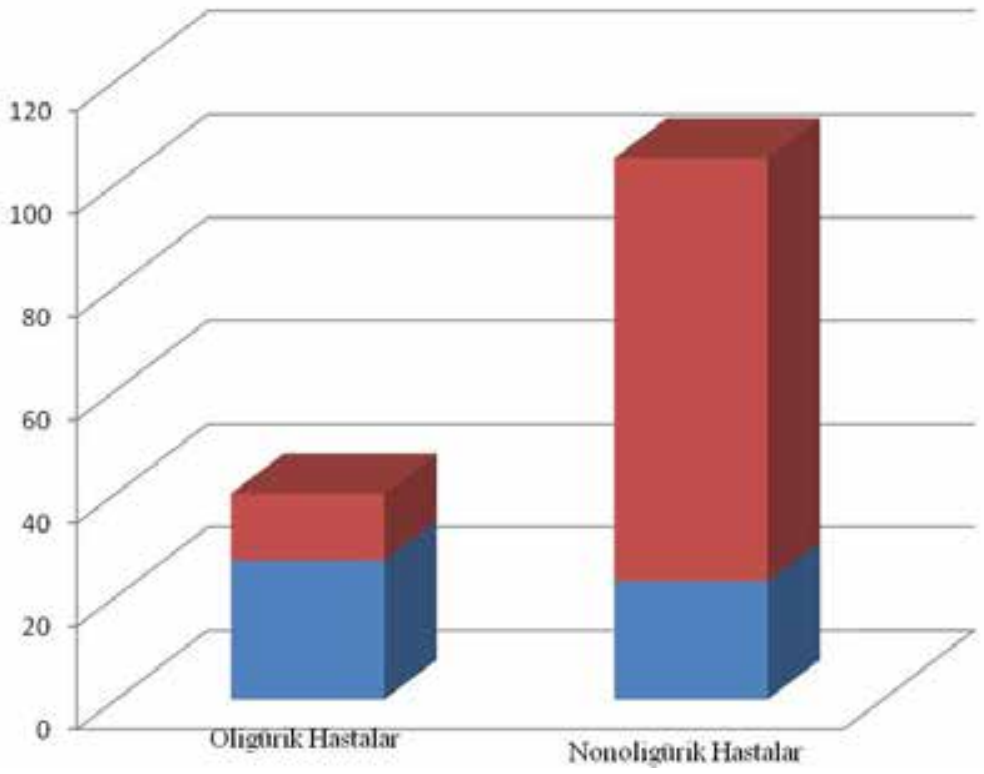

m Medikal Tedavi

- Medilkal Tedavi+HD

Şekil2: Hastaların diürez miktarı ve uygulanan tedavi şekilleri 
tesbit etmişlerdir (17). Kadiroğlu ve ark. 59 hastalık çalışmalarında \%55,9 prerenal azotemi, \%9,9 nefrotoksisite tesbit etmişlerdir (6). Bizim çalışmamızda prerenal azotemi $(\% 38,6)$ ve nefrotoksik ajanlara $(\% 30,3))$ bağlı $A B Y^{\prime} y i$ en sık iki etyolojik neden olarak bulduk. Bu bulgumuz literatür ile uyumluydu.

ABY'de mortalite nedenlere bağlı olarak \%20-40 arasında değişmektedir (18). Bu oran yoğun bakım ünitelerinde \%50-70 lere kadar çıkabilir (19). Utaş ve ark. yaptıkları çalışmada mortaliteyi \%31, Kadiroğlu ve ark. ise çalışmalarında mortaliteyi \%22 olarak bulmuşlardır $(5,6)$ Erem ve ark. 64 olguyu değerlendirdikleri çalışmalarında mortalite oranını \%17,2 olarak bulmuşlardır (20). Öztürk ve ark. mortaliyeyi \%15,1 olarak bildirmişlerdir (16). Biz çalışmamızda mortaliteyi \%13,1 bulduk. Bu değer Öztürk ve Erem'in yaptığı çalışmalarla paralellik gösterirken Utaş ve Kadiroğlu'nun çalışmalarından farklıydı. Bizim çalışmamızdaki mortalite oranlarındaki düşüklük, olguların nisbeten önemli bir kısmının uygun medikal yöntemlerle tedaviye daha iyi yanıt verebilen prerenal azotemi (21) nedenli olmasından kaynaklanıyor olabilir.

$A B Y$ 'de tedavi yöntemlerinden biri de mevcut hipervolomiyi düzeltmek veya hipervolemi gelişimini engellemek için, oligüriyi düzeltmektir. Oligürinin düzeltilmesi hastanın komplikasyonlarını azaltabilirken, mortalite oranını azalttı̆ına dair görüşler de vardır (22-24). Akut Böbrek Yetmezliği'nde oligüri kötü prognoz habercisi olarak bildirilirken (25-30), bazı yazarlar buna karşı görüş bildirmişler ve oligürik hastalarda mortalitede bir artış olmadığını belirtmişlerdir $(16,25,31,32)$. Liangos ve ark. ise tam tersine artmış idrar hacminin daha yüksek bir hastane mortalitesine neden olduğunu belirtmişlerdir (33). Bizim çalışmamızda, oligürik hastalar ve nonoligürik hastalar arasında, mortalite açısından istatiksel olarak anlamlı bir fark yoktu. Bu bulgumuz da literatür ile uyumluydu. Ayrıca oligürik hastalarımızın diyaliz gereksinimi, nonoligürik hastalara göre literatürle uyumlu olarak anlamlı bir şekilde yüksekti (17).

Bazı araştirmacılar ABY'de diyaliz tedavisine ihtiyacın, kötü prognoz belirtisi olduğu bildirmiştir $(34,35)$. San ve ark. hastalarının \%33'ünün diyaliz tedavisi aldığını ve ölen bütün hastaların diyaliz tedavisi alan hastalar olduğunu bildirmişlerdir (15). Liano ve ark. ABY'li hastaların yaklaşık üçte birinde diyaliz tedavisine ihtiyaç duyulduğunu ve de bu hastalarda mortalitenin diyalize ihtiyaç duyulmayan hastalara göre artmış olduğunu bulmuşlardır (25). Abel ve Min Baek de ABY'de diyaliz ihtiyacının kötü prognoz işareti olduğunu bildirdiler (36-38). Erem ve ark. da ölen hastalardaki diyaliz ihtiyacının yaşayan hastalardakine oranla anlamlı derecede yüksek olduğunu bildirmişlerdir (20). Sezer ve ark. yaptığı çalışmada diyaliz gereken ABY'li hastaların \%25 inin öldüğünü bildirmişlerdir (32). Biz de yaptığımız çaIışmada, literatür ile uygun olarak diyaliz tedavisi gereken hastalardaki mortaliteyi, diyaliz tedavisi gerekmeyen hastalara göre anlamlı olarak yüksek bulduk.

Öztürk ve ark. diyabetes mellituslu hastalarla nondiyabetik hastalar arasında mortalite açısından anlamlı bir fark bulmamışlar (17). Biz de çalışmamızda diyabetik hastalarda mortaliteyi daha fazla bulmamıza rağmen, sonuç istatiksel olarak anlamlı değildi. Bazı araştırmacılar hastaların geliş kreatinin seviyelerindeki yüksekliğin mortaliteyi artırdığını ileri sürerken (3941), bazı yazarlar kreatinin seviyesiyle mortalite arasında herhangi bir ilişki bulmamışlardır (42). Bazı yazarlar ise serum kreatinin seviyeleri düşük olanlarda mortaliteyi daha yüksek bulmuşlardır $(17,43,44)$. Biz de çalışmamızda tanı esnasındaki kreatinin seviyeleri yüksek olanlarla düşük olanlar arasında anlamlı bir ilişki bulmadık.

Kadiroğlu ve ark. ABY'de, ölen hastalar ile sağ kalanlar arasında anlamlı bir yaş farkı bulamazken (6), bazı araştırmacılar yaşla birlikte mortalitenin arttı̆̆ını belirtmişler $(17,20,24)$. Bizim çalışmamızda ise yaş ile mortalite arasında anlamlı bir ilişki yoktu.

Sonuç olarak, ABY etyolojisinde 40 yıl öncesine oranla medikal nedenler, bunlar arasında da özellikle hipovolemi ve ilaca bağı nedenler ön plana çıkmaktadır. Hekim kontrolü dışında ilaç kullanımının artması nefrotoksik ajanlara bağlı $A B Y^{\prime}$ nin artmasının nedenlerinden biri olabilir. Ayrıca diyaliz tedavisi gerektiren ABY hastalarında prognozun daha kötü olduğu ve oligoanürik hastalarda diyaliz gereksiniminin arttğı gözlemlenmiştir. Bu yüzden bu grup hastaların daha dikkatle izlemi gerekmektedir. 


\section{KAYNAKLAR}

1. Liano F, Pascual J. Outcomes in acute renal failure. Sem Nephrol 1988;18:541.

2. Dixon BS, Anderson RJ. Nonoliguric acute renal failure. Am J Kidney Dis 1985;6:71-80.

3. Abreo K, Moorthy AV, Osborne M. Changing pattern and outcome of acute renal failure requiring hemodialysis. Arch Intern Med 1986;146:1338-44.

4. Beamen M, Turney JH, Rodger RSC, et al. Changing pattern of acute renal failure Q J Med 1987;62(237):1523.

5. Utas C, Yalcindag C, Taskapan H, et al. Acute renal failure in central anatolia. Nephr Dial Transpl 2000; 15 : 152-5.

6. Kadiroglu AK, Sit D, Atay AE, et al. The evaluation of effects of demographic features, biochemical parameters, and cytokines on clinical outcomes in patients with acute renal failure. Renal failure 2007;29:503-8.

7. Ympa YP, Sakr Y, Reinhart K, Vincent JL. Has mortality from acute renal failure decreased? A systematic review of the literature. Am J Med 2005;118(8):82732.

8. Barretti P, Soares VA. Acute renal failure: Clinical outcome and causes of death. Ren Fail. 1997;19(2):253-7.

9. Fliser $D$, Laville $M$, Covic $A$, et al. A European Renal Best Practice (ERBP) position statement on the Kidney Disease Improving Global Outcomes (KDIGO) clinical practice guidelines on acute kidney injury: part 1 : definitions, conservative management and contrast-induced nephropathy. Nephrol Dial Transplant. 2012 ;27(12):4263-72.

10.Turney JH, Marshall DH, Brownjohn AM, et al. The evolution of acute renal failure, 1956-1988. Q J Med 1990;74:83.

11. Turfanda T, Kocak N, Kadiroglu A, ve ark. Gebeliğe bağlı akut böbrek yetmezliği. Tıp Fak $\mathrm{Mecm}$ 1980;43:691-8.

12. Beaman M, Turney JH, Rodger RSC, et al. Changing patterns and acute renal failure Q J Med 1987;62:15.

13. Abreo K, Moorthy V, Osborne M. Changing patterns and outcomes of acute renal failure requiring hemodialysis. Arch Intern Med 1986;146:1338.
14. Nissenson AR. Acute renal failure: definition and pathogenesis. Kidney Int 1988;66(suppl):7.

15. San A, Selçuk Y, Tonbul Z, et al. Etiology and prognosis in 438 patients with acute renal failure. Renal failure 1996;18:593.

16. Altntepe L, Güney I, Tonbul Z, et al. Assessment of acute renal failure patients treated in our nephrology clinic bettween 1996 and2002. Transplant Proceeding 2005;36:3002-5.

17. Öztürk S, Arpacı D, Yazıcı H, et al. Outcomes of acute renal failure patients requiring intermittent hemodialysis. Renal Failure 2007;29:992.

18. Wang Y, Cui Z, Fan M. Retrospective analyzes on Chinese patients diagnosed with acute renal failure hospitalized during last decade. Am J Nephrol 2005;25:514-9.

19. Kellum JA, leblanc M, Gibrey RT, Tumlin J, lieberthal W, Ronca C. Primary prevention of acute renal failure in critically ill patient. Curr Opin Crit Care 2005;11:53741.

20. Erem C, Sönmez M, Kavgacı H, ve ark. Akut böbrek yetersizliğinde komplikasyonlar ve mortalite. Türk Nefr Diy Trans Der 1995;2:106-10.

21. Kaufman J, Dhakal M, Patel B, Hamburger R. Community-acquired acute renal failure. Am J Kidney Dis 1991;17(2):191-8.

22. Thompson M. Use of essential amino acid/dextrose solution in the nutritional management of patients with acute renal failure . Clin Pharm 1985;19:106-11.

23. Finn WF. Diagnosis and management of acute tubular necrosis. Med Clin North Am 1990;74:873-91.

24. Spiegel DM, Ullian ME, Zerbe GO, Berl T. Determinants survival and recovery in acute renal failure patients dialyzed in intensive care units. Am J Neph 1991;11:44-7.

25. Liano F, Pascual J. Epidemiology of acute renal failure: A prospective, multicenter, community-based study. Madrid Acute Renal Failure Study Group. Kidney Int 1996;50(3):811-18.

26. Jayakumar M, Prabahar MR, Fernando EM. Epidemiologic trend changes in acute renal failure-a tertiary center experience from South India. Ren Fail 2006;28(5):405-410. 
27. Parker RA, Himmelfarb J, Tolkoff-Rubin N, Chandran $\mathrm{P}$, Wingard RL, Hakim RM. Prognosis of patients with acute renal failure requiring dialysis: Results of a multicenter study. Am J Kidney Dis 1998;32:432-43.

28. Wang IK, Wang ST, Lin CL. Early prognostic factors in patients with acute renal failure requiring dialysis. Ren Fail 2006;28:43-9.

29. Cantarovich F, Verho MT. A simple prognostic index for patients with acute renal failure requiring dialysis. French Multicentric Prospective Study on Furosemide in Acute Renal Failure Requiring Dialysis. Ren Fail 1996;18:585-92.

30. Bullock ML, Umen AJ, Finkelstein M, Keane WF. The assessment of risk factors in 462 patients with acute renal failure. Am J Kidney Dis 1985;5:97-103.

31. Gillum DM, Dixon BS, Yanover MJ, et al. The role of intensivedialysis in acute renal failure. Clin Nephrol 1986;25:249-55.

32. Sezer MT, Demir M, Gungor G, Senol A . Predictors of mortality in patients with acute renal failure. Acta Medica 2006;49:183-8.

33. Liangos O, Rao M, Balakrishnan VS. Relationship of urine output to dialysis initiation and mortality in acute renal failure. Nephron Clin Pract 2005;99(2):c56-c60.

34. Lennon AM, Coleman PL, Brady HR. Management and outcome of acute renal failure. In: Johnson RJ, Feehally J. Comphrensiva of clinical nephrology. Barcelona: Harcourt; 2000, p4.

35. Cantarovich F, Bodin L, Functional acute renal failure. In:Cantarovich F, Rangoonwala B, Verho M: progress in acute renal failure. NJ: Hoechst Marion Roussel; 1998, p55.
36. Abel RM. Nutritional support in the patients acute renal failure. J Am Col N 1983;2:33-44.

37. Abel RM, Beck GH, Abbott WM, Ryan JA, Barnet $\mathrm{GO}$, Fischer JE. Improved survival from acute renal failure after treatment with intravenous essentional L-amino acids and glucose. N Eng J Med 1973;288:695-9.

38. Min Baek S, Makaboli GG, Brayn-Brown LW, Kusek J, Shoemaker WL, The influence of parenteral nutrition on the course of acute renal failure. Surgery Gynecol Obstet 1975;141:405-8.

39. Lima EQ, Dirce MT, Castro I, Yu L. Mortality risk factors and validation of severity scoring systems in critically ill patients with acute renal failure. Ren Fail 2005;27:547-56.

40. Zang L,Wang $\mathrm{M}$,Wang $\mathrm{H}$. Acute renal failure in chronic kidney disease-clinical and pathological analysis of 104 cases. Clin Nephrol 2005;63:346-50.

41. Jayakumar M, Prabahar MR, Fernando EM. Epidemiologic trend changes in acute renal failure-a tertiary center experience from South India. Ren Fail 2006;28(5):405-10.

42. Obialo $\mathrm{Cl}$, Okonofua EC, Nzerue MC, Tayade AS, Riley LJ. Role of hypoalbuminemia and hypocholesterolemia as copredictors of mortality in acute renal failure. Kidney Int 1999;56(3):1058-63.

43. Chertow GM, Soroko SH, Paganini EP, et al. Mortality after acute renal failure: Models for prognostic stratificationand risk adjustment. Kidney Int 2006;70(6):1120-6.

44. Chertow GM, Lazarus JM. Intensity of dialysis in renal failure. Semin Dial 1996;9:476-80. 